\title{
ECONOMY
}

\section{FINANCIAL SYSTEM DEVELOPMENT IN REPUBLIC OF MOLDOVA IN THE CONTEXT OF THE NEW INTERNATIONAL FINANCIAL ARCHITECTURE}

\author{
PhD in Economics, Assistant Professor Lopotenco Viorica \\ Republic of Moldova, Chisinau, Academy of Economic Studies of Moldova
}

DOI: https://doi.org/10.31435/rsglobal_ws/31102019/6723

\begin{abstract}
ARTICLE INFO
Received: 16 August 2019

Accepted: 10 October 2019

Published: 31 October 2019

\section{KEYWORDS}

new international financial architecture;

national financial system;

financial regulation;

financial market development.

ABSTRACT

The primary purpose of this paper is to analyze the transformations in the international financial architecture and their impact on the national financial system. For this purpose, a multi-criteria analysis (matrix approach) is used, which represents a structured approach used to determine the general preferences between several alternative options, which lead to the achievement of several objectives. The approach of the matrix gives the possibility to combine the size of the set of the financial sector.

The conclusions of this study consist in the fact that the complex resolution of the challenges in the international financial architecture implies the creation of foundations for the implementation of the progressive structural changes in the economy, capable of contributing to the sustainable economic development.
\end{abstract}

Citation: Lopotenco Viorica. (2019) Financial System Development in Republic of Moldova in the Context of the New International Financial Architecture. World Science. 10(50), Vol.2. doi: 10.31435/rsglobal_ws/31102019/6723

Copyright: (C) 2019 Lopotenco Viorica. This is an open-access article distributed under the terms of the Creative Commons Attribution License (CC BY). The use, distribution or reproduction in other forums is permitted, provided the original author(s) or licensor are credited and that the original publication in this journal is cited, in accordance with accepted academic practice. No use, distribution or reproduction is permitted which does not comply with these terms.

Introduction. The development of international financial architecture in the last decade is characterized by significant fundamental changes in its structure, the emergence of new trends, instruments, regulators, and institutions within them. Financial globalization has helped to strengthen the interconnection and interdependence of national financial systems and allowed them to operate both regionally and globally. The new financial architecture was defined by an accelerated movement of capital not only at the global level but also at the regional and national levels. However, on the other hand, despite positive changes, especially in developing countries, in the process of their involvement in the global and regional structure of international financial architecture, the vulnerability and interdependence of the main segments of their national financial markets have increased.

The international monetary system is a multilateral one, is under continuous tension, in a rapidly changing global environment. While this process, on the one hand, forces global financial governance to revise existing international agreements, as well as open the doors for global financial institutions as well as those at the national level to suit its purposes.

Financial globalization has a multidirectional effect on the level of development of national financial systems, which is manifested on the one hand in the increase of cross-border financial transactions, the emergence of new financial institutions, and on the other: in changing the dynamics and mechanisms of contagion of financial crises, increasing the use of funds borrowed by financial institutions and taking on higher risks. Forming a strategy for developing the national financial architecture in the context of a sustainable economy should take these changes into account. As a result, measures have been developed to overcome the fragmentation of national financial regulations as an urgent scientific and practical task. 
In the condition of the transformation of the international financial architecture at the level of the national financial system, the banking system is a crucial element in ensuring the stability of the financial system. The formation of a model of the banking system in the Republic of Moldova in the context of the new realities of the global financial architecture should take place in the following areas: ensuring the effective redistribution of capital within the banking system; formation of banking standards for risk management, taking into account the cyclical nature of economic development; increasing domestic sources of savings; further consolidation of the Moldovan banking sector.

The present study will have the following structure: in the second section a review of the specialized literature will be presented; In the third section the empirical methodology of the research will be described; the data and results of the application of the methodology and their implications will be analyzed in the fourth section; In section five the research conclusions will be presented.

The essential purpose of this study is the empirical research on the quality of the banking system in the Republic of Moldova within the new international monetary order.

Literature review. The popularization of the term international financial architecture is attributed to Barry Eichengreen after the publication of the paper "Toward a New International Financial Architecture," edited by the Peterson Institute [1]. According to Barry Eichengreen, the Asian financial crisis and the global economic crisis that followed highlighted the need to prevent and manage financial crises quickly. The author also referred to concerns about existing institutional arrangements, including institutions founded in Bretton Woods, which could no longer adequately address the current reality of high capital mobility. The recommendations were based on the belief that financial markets can malfunction, provoking convincing arguments for a financial security system (and therefore a role for the IMF), but also creating moral hazard issues that need to be addressed.

The new financial architecture consists of codes of conduct, a new global regulator, and an international memorandum of understanding, which clearly defines responsibility for crisis prevention and resolution. Gordon Brown's vision is not about new institutions, but how we behave in the interdependent world, respect discipline, and reach solutions in a more coordinated way. The fundamental challenge that lies ahead is the definition of new rules of the game, which, by increasing the credibility and confidence of investors, contribute to stability and prosperity [2].

According to Andrew Crockett, "architecture" may seem a pretentious word to describe the ad-hoc set of arrangements that make up the current international monetary system. Even in a reformed international monetary system, the clarity of structure and design that are the hallmarks of good architecture will certainly be lacking. However, a financial system should, however, conform to certain general principles, which could be readily understood and widely accepted [3].

The new international financial architecture, according to Nicholas Hopkinson, involves rules and conventions in governing international economic and financial relations and institutional arrangements for developing, monitoring, and enforcing the rules. The current international financial architecture is a market system based on flexible exchange rates, market-determined adjustments, endogenous liquidity created, and open capital markets. Strengthening the architecture may involve crisis prevention (strengthening the functioning of the market), crisis management, and resolution (strengthening institutional responses). Crisis prevention involves better macroeconomic policies (international surveillance) and stronger financial systems (development and application of prudent codes of conduct). Robust macroeconomic policies require sustainable budgets, structural policies, and avoidance of fixed regimes that cannot be adjusted [4].

Methodology and data. Scientists and, in particular, philosophers know the importance of the scholastic approach, which simplifies existing knowledge, keeps information-overloaded and broadens human minds for new ideas. The trend of simplicity, for example, is shared by Klaas Knot, president of DE Nederlandsche Bank, who stressed that the financial sector could be considered one of the most complex areas in today world. Clear and simple businesses that will help reduce complexity Banks must focus again on transforming maturity and lending to the real economy [5]. According to Andy Haldane, head of financial stability at the Bank of England, Banking and financial regulation should be simplified if no further crisis is desired [6]. Furthermore, Jeffry Pilcher argues that financial institutions need to make money quickly and protect people [7].

The scope of financial system analysis and development evaluation is quite broad and, therefore, the structural issues cannot only be broken down into autonomous segments that correspond to existing institutional arrangements. Structural and development issues arise across the entire range of financial and intermediary markets, including banking, insurance, securities markets, and non- 
banking intermediation. These often require consideration of factors for which a well-adapted and standardized quantification is not available. Therefore, the challenge is to translate those broad and somewhat abstract concepts into a concrete and practical evaluation methodology.

Table 1. The financial system matrix

\begin{tabular}{|c|c|}
\hline \multirow[t]{2}{*}{ CATEGORY } & INDICATORS \\
\hline & Financial Institutions \\
\hline \multirow[t]{4}{*}{ Depth } & Private-sector credit to GDP \\
\hline & Pension fund assets to GDP \\
\hline & Mutual fund assets to GDP \\
\hline & Insurance premiums, life and non-life to GDP \\
\hline \multirow[t]{6}{*}{ Access } & Bank branches per 100,000 adults \\
\hline & ATMs per 100,000 adults \\
\hline & Average loan and deposit size \\
\hline & Loan \& deposit accounts per capita \\
\hline & $\%$ of people with bank account \\
\hline & Collateral needed for loan \\
\hline \multirow[t]{8}{*}{ Stability } & Capital adequacy ratio \\
\hline & Lenders Non-performing loans \\
\hline & Real credit growth \\
\hline & Loan concentration \\
\hline & Large loan exposures to capital \\
\hline & Liquid asset ratio \\
\hline & Net FX position-to-capital \\
\hline & Default probability of banks \\
\hline \multirow[t]{6}{*}{ Efficiency } & Net interest margin \\
\hline & Lending-deposits spread \\
\hline & Non-interest income to total income \\
\hline & Overhead costs to total assets \\
\hline & Return on assets \\
\hline & Return on equity \\
\hline & Financial Markets \\
\hline \multirow{5}{*}{ Depth } & Stock market capitalization to GDP \\
\hline & Stocks traded to GDP \\
\hline & International debt securities of government to GDP \\
\hline & Total debt securities of financial corporations to GDP \\
\hline & Total debt securities of nonfinancial corporations to GDP \\
\hline \multirow[t]{4}{*}{ Access } & $\begin{array}{l}\text { Access Percent of market capitalization outside of top } 10 \text { largest } \\
\text { companies }\end{array}$ \\
\hline & $\begin{array}{l}\text { Total number of issuers of debt (domestic and external, nonfinancial } \\
\text { and financial corporations) }\end{array}$ \\
\hline & Number of issuers, bonds listed and newly listed \\
\hline & Foreign issues in local currencies \\
\hline \multirow[t]{3}{*}{ Efficiency } & Efficiency Stock market turnover ratio (stocks traded to capitalization) \\
\hline & Daily stock returns \\
\hline & Daily trading volume data \\
\hline \multirow[t]{3}{*}{ Stability } & Skewness of market return index \\
\hline & Vulnerability to earnings manipulation \\
\hline & Duration (measuring equity risk) \\
\hline
\end{tabular}

Source: [8]

The proposed methodology starts with an evaluation of the facts, which aim to evaluate the existing financial services provided (and available) to the national economy - in terms of range, scale, cost coverage, and quality - vis-à-vis international practice. Such an evaluation should contribute to the identification of areas with low systemic performance, which can be further analyzed to diagnose the causes of under-performance against realistic goals. To some extent, benchmarking can be quantified, but 
in practice, quantification should be supplemented with qualitative and detailed information. The question that may arise, if the quality or quantity is insufficient, then what caused this deficit? Deficiencies will often be attributed to a wide range of structural, institutional, and political factors.

First, there may be gaps or changes in the financial infrastructure, both in the software infrastructures of the legal, information, and regulatory systems, and in the more difficult transactional technological infrastructures, which include payment and settlement systems and communications in general.

Secondly, there may be defects or adjustments needed in the regulatory or fiscal policy (including competition policy) whose inadequacy or unintended side effects distort or suppress the functioning of the financial system to some extent, which is not justified by the policy objectives.

Third, it needs to be dug more in-depth, there may be broad issues of governance at the national level, for example, if existing institutional structures impede the proper development of policies (especially favoring current operators over newcomers).

Fourth, deficiencies in the financial sector can also be traced to issues related to the country's broader economic infrastructure, including education, transportation, and communications systems. In addition, many developing countries face difficulties in the fact that efficient financing requires a range of activities that may be inaccessible to small countries, populated by a small number of low customers, small intermediaries, and small organized markets [9].

The diversity of financial systems in different countries implies that more indicators need to be used to analyze modern national financial systems. In such situations, multi-criteria analysis (matrix approach), which represents a structured approach, is used to determine the general preferences of several alternative options, which lead to the achievement of some objectives. The approach of the matrix gives the possibility to combine the size of the set of a financial sector, in our case - depth, access, stability, efficiency - with the traditional financial subsectors, such as the bank, capital markets, etc. (table 1).

Empirical analysis and results. The lessons of the international financial crisis have led to a substantial transformation of financial activity at the international level, to the revision of financial strategies, to changes in the principles of financial regulation, and the massive state support for the banking sector has significantly changed the balance of power in the global competition. In recent years, we have witnessed a series of changes in the international financial architecture that has, without doubt, an impact on national financial systems.

The global crisis has highlighted shortcomings in financial regulation and demonstrated the need for systemic work with the financial sector as a whole. Thus, the need for the proper regulation of markets and operations was imposed, which would reflect the relationship between banks and between banks and other participants in the financial system. This led to the shift of the strategic focus for macro-prudential supervision, as opposed to micro-prudential supervision.

In the context of recent developments in the field of financial supervision and the Republic of Moldova, it has been necessary to create a legislative framework that allows the integration of the supervisory function at the national level (the transition from the classic model of supervision with separate sectorial institutions to the consolidated model). The Republic of Moldova has made an essential commitment under the Association Agreement, which implies the gradual and dynamic harmonization of the national legislation with the European Union legislation. As a result of this process, progress was also made regarding the quality of the Moldovan financial system.

The level of quality of the financial sector of the Republic of Moldova is determined by the fundamental characteristics of the socio-economic situation of the country: diversification of the economy, level of population welfare, development of state and legal institutions, degree of integration of the internal financial market in the global capital markets and others. The model of the Moldovan financial system is, in many respects, similar to that of other emerging countries. Its main characteristics are the dominance of the banking system in the financial system (the assets of the banking system in 2018 constituted approximately $88.73 \%$ of total assets of the financial system in the Republic of Moldova [10]), the weak development of the capital market and the absence of a substantial investor base. Institutions represented by insurance companies and pension funds, limit the economy's ability to transform the population's economies into long-term investments needed for sustainable economic growth and improving the well-being of citizens.

The financial market in the Republic of Moldova is characterized by a rather high level of concentration in the banking sector, where the five largest credit organizations represent $83.99 \%$ of the total assets of the entire sector [12]. The activity of the population on the financial market remains low. Bank deposits dominate the structure of population economics, which is mostly due to a historically reliable view of banks vis-a-vis non-bank financial intermediaries. 


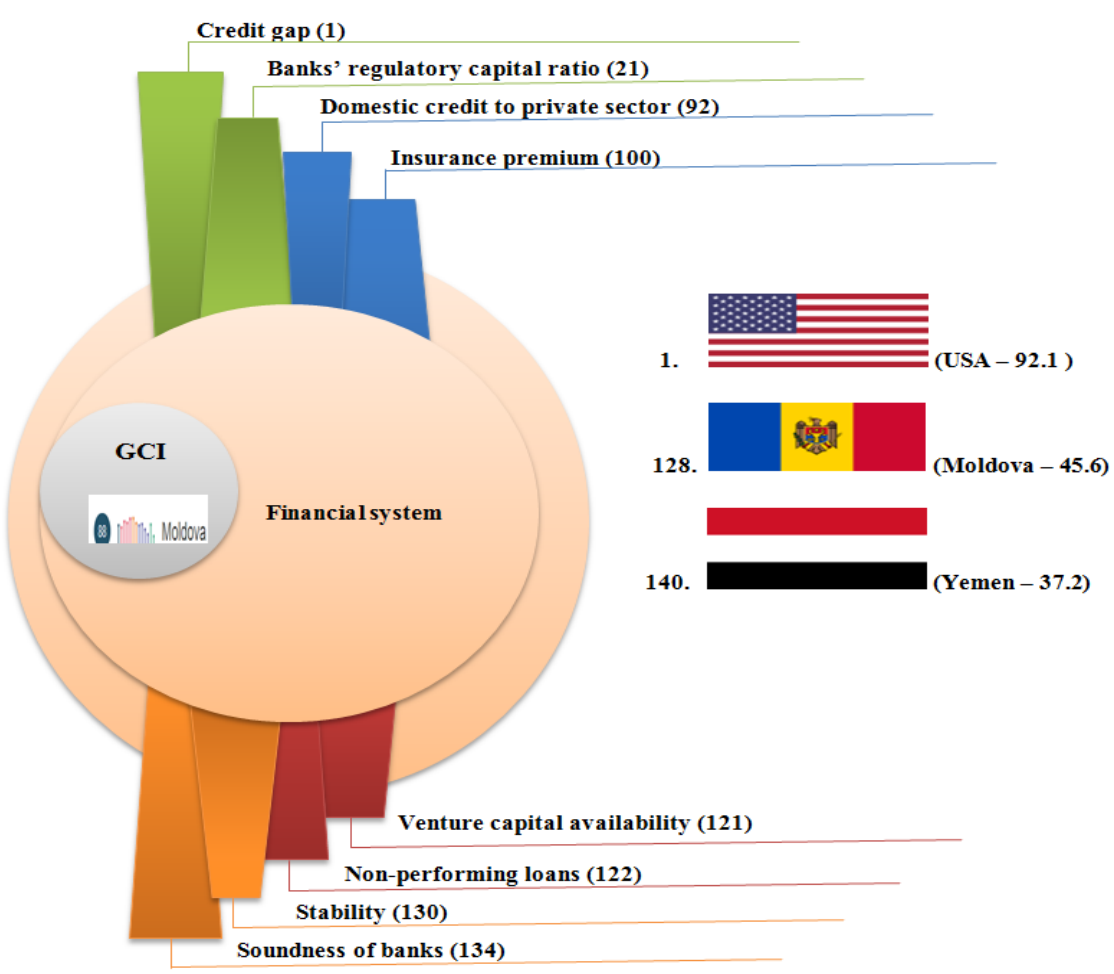

Fig. 1. Financial system pillar of the Global Competitiveness, 2018

Source: [11]

The quality of the financial system is particularly crucial for the countries of Central and Eastern Europe, where modern financial systems have been built close to zero. We can see the state of the Moldovan banking system through the GCI ranking, the 9th pillar: Financial system.

From figure 1, it can be observed that in the Moldovan financial system, there are a number of problems that should be urgently overcome. In terms of the financial system, according to the data World Economic Forum Global Competitiveness Index, The Republic of Moldova has an alarming situation compared to the countries of the region.

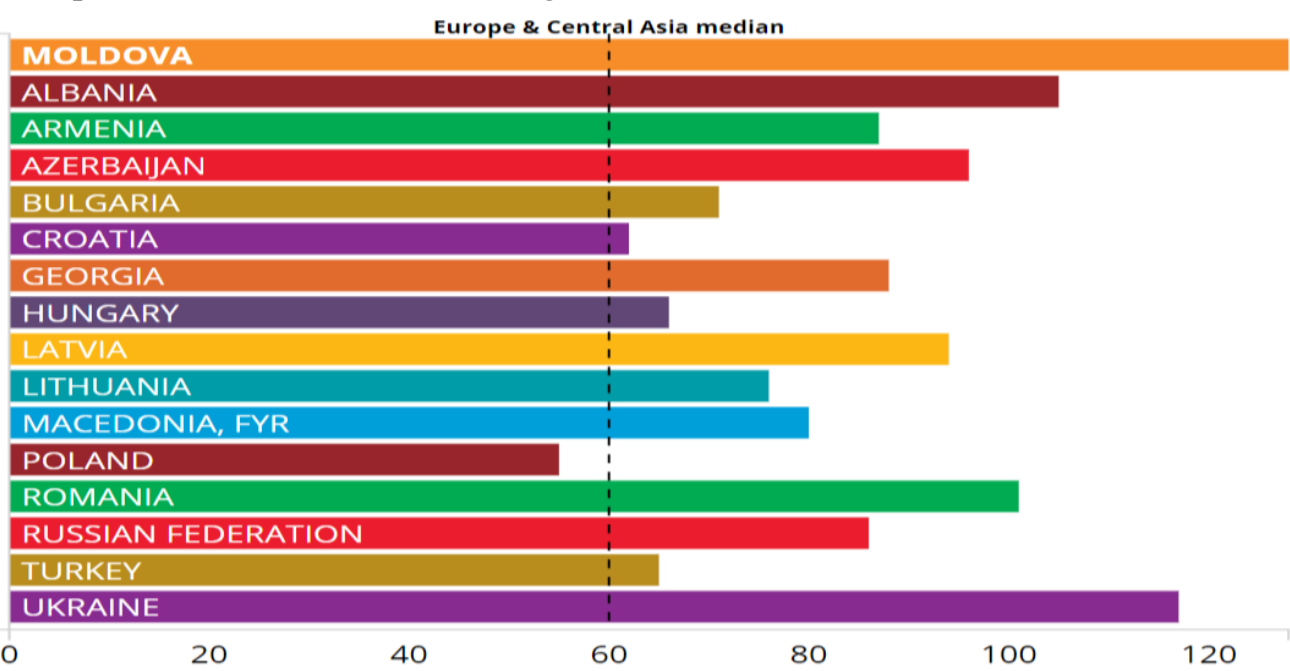

Fig. 2. Financial System, Rank (Europa\&Central Asia)

Source: [13]

Based on the state of the financial system of the Republic of Moldova, its main development directions should be necessarily holistic, and the maximum effect of the implementation should be achieved only with the integrated implementation of the measures by all parties involved in the functioning of the financial system.

Central monetary authorities, in this regard, make great efforts to overcome the situation created. Thus, the reform of the financial-banking sector has as main directions following action:

- strict supervision of the financial and banking system; 
- promoting more stable financial institutions and integrated financial markets;

- ensuring good corporate governance in the financial-banking sector;

- defending the interests of the clients of the banks by guaranteeing the deposits and providing compensations, as well as correct informing them about the risks of the financial products promoted;

- promoting a banking system oriented towards supporting the real economy and promoting a sustainable economic growth.

Conclusions. Under the conditions of globalization, the challenges facing the economy of the Republic of Moldova are becoming increasingly pronounced. The complex resolution of these challenges implies the creation of some foundations for the implementation of progressive structural changes in the economy, capable of contributing to sustainable economic development.

The fundamental mission of the financial system is to provide financial services, which must meet the demands of the economy and society in increasing the level of investments and social stability. In order for the financial system of the Republic of Moldova to meet the needs of the economy and society, a concept is needed that highlights the following:

- the needs of the real sector of the economy in resources for completing the circulating means, expanding the production base, renovating the infrastructure; without these resources, innovative growth and efficient development are not possible;

- ensuring the demand of the population for financial instruments to protect and increase the standard of living achieved; thus, the financial sector contributes to achieving the social stability necessary for the population and ensuring the minimum social guarantees

- the needs of the state in maximizing the added value established on the territory of the country and the financial infrastructure for carrying out the economic policy meant to contribute to ensuring sustainable economic growth and the competitiveness of the economy

The degree of development of the financial system and its essential element - the banking system largely determines the real possibilities of the economy of the Republic of Moldova. The Moldovan banking system is a vital component of the national infrastructure, which determines the efficiency of transforming the economies into investments and at the same time, the competitiveness of the economy of the Republic of Moldova.

\section{REFERENCES}

1. Eichengreen, B. (2009). Toward a New International Financial Architecture. Washington, D.C.: Peterson Institute for International Economics. ISBN: 9780881322705

2. Brown, G. (1998). A New Global Financial Architecture. In: The Wall Street Journal Europe, October. ISSN: 0921-9986

3. Crockett, A. (2009). Reforming the Global Financial Architecture. In: Asia and the Global Financial Crisis. Conference sponsored by the Federal Reserve Bank of San Francisco, Santa Barbara, Oct 18-20. p.191-201

4. Hopkinson, N. (2000). Managing the Global Economy: Prospects for a New Financial Architecture and Economic Recovery. In: The Brown Journal of World Affairs, Vol. 7, No. 2, Summer/Fall. pp. 129-140. ISSN: 1080-0786

5. Knot, K. (2013). Simplicity in the financial sector. In: at the 20th RiskMinds Global Risk Regulation Summit, Amsterdam, 2 December [online]. http://www.bis.org/events/agm2011/sp110626.pdf

6. Haldane, A. (2012). Tails of the unexpected. In: The Credit Crisis Five Years On: Unpacking the Crisis, conference held at the University of Edinburgh Business School, 8-9 June [online]. https://pdfs.semanticscholar.org/55bd/31941afbbd1072b0b022971b3ab479db6c0d.pdf

7. Pilcher J. The Simplicity Revolution in Banking. In: The Financial Brand [online]. https://thefinancialbrand.com/51734/the-simplicity-revolution-in-banking/

8. The World Bank Financial Sector Operations and Policy. Financial Sector Development Indicators. [online]. http://siteresources.worldbank.org/INTTOPACCFINSER/Resources/Webintro.pdf; Financial Sector Operations and Policy. Measuring banking sector development. [online]. http://siteresources.worldbank.org/INTTOPACCFINSER/Resources/Banking.pdf

9. Bossone, B., Honohan, P., Long, M. (2001). Policy for Small Financial Systems. In: Financial Sector Policy for Developing Countries. New York: Oxford University Press. pp. 95-128. [online]. https://pdfs.semanticscholar.org/a067/fe14b5d1d07fe6823fc043a357b115418150.pdf

10. Informație privind activitatea economico-financiară a băncilor din RM. [online]. http://www.bnm.md/bdi/pages/reports/drsb/DRSB1.xhtml?id=0\&lang=ro

11. The Global Competitiveness Report 2018. [online]. http://www3.weforum.org/docs/GCR2018/05FullReport/The GlobalCompetitivenessReport2018.pdf

12. Informație privind activitatea economico-financiară a băncilor din RM. [online]. http://www.bnm.md/bdi/pages/reports/drsb/DRSB1.xhtml?id=0\&lang=ro

13. The Financial Market Development Index is one of the Global Competitiveness Pillars. [online]. https://tcdata360.w orldbank.org/indicators/inn.fin.mkt.dev?country=BRA\&indicator=740\&viz=line_chart\&years=2007,2018 